\title{
Hughes tops league of US charities
}

\section{Washington}

THE Hughes Medical Institute became the world's wealthiest charity last week when it sold off Hughes Aircraft Company to General Motors for an estimated $\$ 5,000$ million. Dr Donald Frederickson, president of the institute and former director of the National Institutes of Health $(\mathrm{NIH})$, said the new endowment should allow the institute to more than double the $\$ 100$ million it currently spends each year on medical research in genetics, immunology, neurosciences and metabolic control.

The sale also marks a further step in the demystification of the institute, which has been something of an enigma even to the scientists it supports. There is no such thing as applying to the Hughes Institute for a research grant; it only gives money to "affiliate" laboratories, of which there are now eighteen, on medical school campuses around the United States. The institute pays the salaries of the 200 or so scientists who work in these laboratories and leases the buildings from the universities. The most recent campus to join the select ranks is the University of California, San Diego and the Salk Institute. Others include Harvard, Yale, Johns Hopkins and Stanford Universities.

Like its mysterious founder, the institute has tended to operate beyond the public view. It has often been criticized for failing to maintain any open criteria (including peer review) for selecting researchers and projects to support.

That has changed dramatically, however, since Frederickson took charge in 1983, following a court fight in Delaware (where the institute is legally incorporated). In the same year, Delaware's attorney general succeeded in removing most of Hughes's former associates from the board of trustees.

The Hughes Institute's $\$ 5,000$ million places it far ahead of any other charitable organization or foundation. The Ford Foundation, its closest competitor, has an endowment of $\$ 3,500$ million. The Battelle Memorial Institute, which had previously been the largest independent research institute, has assets of only $\$ 250$ million.

Frederickson estimates that total public and private support of basic biomedical research totals $\$ 1,500-2,000$ million in the United States; the Hughes Institute will thus be managing some $10-20$ per cent of that total. By comparison, the budget of $\mathrm{NIH}$ is to be $\$ 5,200$ million next year, though much of that is for clinical and applied research.

Frederickson expects the eighteen existing affiliate programmes to be expanded, as will a new scheme that he initiated to encourage medical students to consider research careers. Under this scheme, to which the institute has contributed $\$ 10$ million, students can spend one year working at NIH with senior researchers. The 30 Hughes Research Scholars will live and work in the former Sisters of the Visitation Convent adjacent to the NIH campus; the convent is being renovated with the Hughes Institute funds.

Frederickson said the trustees are in the process of deciding whether the institute should continue business as a "medical research organization" - which, under federal tax laws, means it must conduct the research itself - or instead become a private foundation, which would allow it to make grants and expand its horizons to include medical ethics, scientific communication and science education. Medical re- search organizations are required by law to spend 3.5 per cent of their assets each year exclusively on "continuous conduct of medical research". For foundations the figure is 5 per cent and they must also pay an excise tax of 1-2 per cent on income. In addition, foundations are subject to restrictions on their business activities.

The sale of the Hughes Aircraft Company has also removed the institute's lingering tax problems. Hughes set up the institute in 1953 as a non-profit organization which, on paper, owned Hughes Aircraft - the piece of his industrial empire that now builds defence electronics but no aircraft. For many years the Internal Revenue Service contended that the institute was being used as a tax shelter by Hughes, noting that very little of the Hughes Aircraft profits actually reached the institute. Before 1976, when Hughes died, the institute had never received more than $\$ 4.2$ million in any one year from the company. Although it was eventually acknowledged that the institute was legitimately engaged in conducting medical research, other tax problems have remained.

Stephen Budiansky

\section{Japan in space}

\section{Carp to loop the loop?}

\section{Tokyo}

JAPAN'S first astronaut, who may be a woman, is scheduled to blast off in the US space shuttle in early 1988 with a chicken egg, two carp, some soyabean seeds and 20,000 fruit-fly larvae stored in Japan's section of the Spacelab Module. Not intended for eating, these organisms are vital components in a series of life science experiments designed to shed light on the effects of space travel on man.

Details of the fruit-fly experiment were revealed at a symposium held in Tokyo last week. The fruit fly Drosophila, which has been subject to more than its fair share of radiation on Earth, will be used to assess the possible effects on human beings of long-term exposure to space radiation, including $\mathrm{X}$-rays, low-energy protons and neutrons and high-energy cosmic radiation. The larvae will be carried in an incubator aboard the spaceship and returned to Earth once they have grown to become pupae. According to Professor Mitsuo Ikenaga of Kyoto University, exposure to radiation should cause curling and/or multiplication of hairs on the wings of the adult insects, thereby providing information about chromosomal changes induced by the radiation.

In a closely related experiment, soyabean seeds will be cultivated on return to Earth and mutations in the adult plants will be easily detectable from the colour of their leaves. But Taro Fujii, head of the Plant Section of the National Institute of Genetics, fears that the degree of exposure to radiation aboard the shuttle may be insufficient to produce mutations.

In a study of space motion sickness, the behaviour and brain-wave activity of two carp in the weightlessness of space will be examined.

A decade ago aboard Skylab, fish were observed to perform strange looping movements for the first 3-4 days in space which corresponds to the duration of disorientation reported by mission specialists. In Japan's experiment, otoliths, which give the fish its sense of balance, will be removed from one of the carp and the effects of light on the fish monitored normal carp turn their back toward a light source.

A preliminary experiment has already been carried out by Japan's Institute of Space and Astronautical Science (ISAS) in which one carp and three goldfish in a rocket-shaped capsule were dropped from a balloon at an altitude of $30,000 \mathrm{~m}$. During the 20-second free fall, the carp showed promising behaviour, although the goldfish died during the ascent of the balloon. In another experiment a fertilized chicken egg will be hatched and the effects of weightlessness on the chick's bone cells examined.

The Japanese astronaut responsible for looking after these and other experiments has yet to be selected. Of 533 applicants for the job, seven remain after three stages of screening by Japan's National Space Development Agency. These seven, including one woman, Chiaki Naito, will undergo final aptitude trials at the Johnson Space Center in Houston, Texas, beginning on 20 June, and around September three will be selected, of whom one will join the space shuttle flight scheduled for 27 January 1988.
David Swinbanks 